\title{
Effects of Content-Based Instruction to Non-English-Major Undergraduates English Teaching with Internet-Based Language Laboratory Support
}

\author{
Yougen Lou', Pei Xu' ${ }^{2}$ \\ ${ }^{1}$ School of Foreign Studies, Yangtze University, Jingzhou, China \\ ${ }^{2}$ Paotong Elementary School, Wuhan, China \\ Email: louyougen@163.com
}

Received 3 March 2016; accepted 10 April 2016; published 13 April 2016

Copyright (C) 2016 by authors and Scientific Research Publishing Inc.

This work is licensed under the Creative Commons Attribution International License (CC BY). http://creativecommons.org/licenses/by/4.0/

(c) (i) Open Access

\begin{abstract}
With development of technology of computer and internet, it is a beneficial attempt to the reform of College English Teaching based on the subject content with Internet-Based Language Laboratory support for non-English-majored undergraduate students. Content-Based Instruction (CBI) has been defined as "the teaching of content information in the language being learned with little or no direct or explicit effort to teach the language itself separately from the content being taught", which can make non-English-majored undergraduate students not only learn subject knowledge but also improve their foreign language (English) ability in learning content in Internet-Based Language Laboratory (IBLL). 90 non-English-majored undergraduate students in Yangtze University participated in this study for one-year experiment to investigate effects of CBI English teaching with IBLL support. Results in this study showed that: 1) Compared with the control group (CG), both CBI English teaching and CBI English teaching with IBLL support could improve the level of English learning motivation of non-English-majored undergraduate students in their English learning, and CBI English teaching with IBLL support is better in enhancing the level of English learning motivation; 2) compared with the control group (CG), both CBI English teaching and CBI English teaching with IBLL support could improve the level of English language applied ability of non-English-majored undergraduate students in their English learning, and CBI English teaching with IBLL support is better in enhancing the level of English language applied ability; 3 ) both CBI English teaching and CBI English teaching with IBLL support are limited for some non-Englishmajored undergraduate students with poor foreign language (English) basis.
\end{abstract}

\section{Keywords}

CBI, Undergraduate College English Teaching, IBLL

How to cite this paper: Lou, Y. G., \& Xu, P. (2016). Effects of Content-Based Instruction to Non-English-Major Undergraduates English Teaching with Internet-Based Language Laboratory Support. Creative Education, 7, 596-603. 


\section{Introduction}

College English is a required course for every student in colleges or universities in mainland China. The purpose of College English teaching in mainland China is to develop students' English language proficiency, especially in listening and speaking skills, so that they can use English to communicate effectively in the future study, work and social interactions, while enhancing their self-learning ability and cultural awareness to adapt to the development of our society and to meet the need for international exchanges. How to meet the purpose of College English teaching is a difficult question for English teachers in mainland China to solve. The method of Content-Based Instruction (CBI) combined with Internet-Based Language Laboratory (IBLL) will be one of answers to solve the question above. The purpose of this study is to investigate whether the method of CBI and the method of CBI with IBLL support help non-English-majored undergraduate students learn English better, compared with the traditional English teaching method.

Content-Based Instruction (CBI) has been defined as "the teaching of content or information in the language being learned with little or no direct or explicit effort to teach the language itself separately from the content being taught” (Krahnke, as cited in Richards \& Rodgers, 2001). This teaching approach is considered by many researchers an effective and realistic teaching method in terms of combining language and content learning. According to Crandall (1999), CBI can be used in various ways depending on the skills being taught and includes not only traditional teaching methods such as grammar-based instruction or vocabulary development but also contemporary approaches such as communicative language teaching and humanistic methods. Content-Based Instruction is based on three main theories of language and four teaching models. Three main theories of language are: "language is text and discourse-based," "language use draws on integrated skills," and "language is purposeful" (Crandall, 1999). Four teaching models are "theme-based approach", "sheltered-content courses", "adjunct courses", "language for special purposes".

CBI in foreign language teaching has been used to improve students' subject knowledge and cognitive ability, promote the improvement of its language (Mohan, 1986). CBI was born in immersion program teaching experiment in Montreal, Canada in 1960s. CBI in foreign language teaching in foreign countries had many successful examples (Benesch, 1988; Brinton et al., 1989; Kasper, 1994, 1997; Chumpavan, 2001; Valeo, 2013). Some scholars (Lv, 2001; Li, 2002) in China suggested that foreign (English) language teaching form should becombined foreign (English) language with content. There were teaching researches (Yu \& Han, 2003) based on the combination of foreign language and the subject content in the college English teaching environment in China, but CBI in non-English-majored undergraduate students' English teaching research is still at groping stage in China.

\section{Research Methods}

\subsection{Subjects}

In September 2014, 90 first-year non-English-majored undergraduates in 3 classes from Yangtze University participated in this study. Among the 90 subjects, 48 were females and 42 males, average age 19 with Chinese as the main language. Their majors were chemistry, agriculture, plant protection, biological technology. All 90 non-English-majored undergraduates were taught by the same teacher during two years. All 90 students who had learned College English the first year. And the second year, 90 non-English-majored undergraduates were divided randomly into three groups. One group of 30 non-English-majored undergraduates was regarded as the Control Group (CG) with the traditional College English teaching method and other 60 non-English-majored undergraduates were divided averagely, randomly, as Experiment Group1 and Experiment Group 2 (EG1 with CBI English teaching and EG2 with combining CBI with IBLL support). Both CG and EG, their level of education, family background, age, personality and life experiences and other factors were same, that was to say, their overall learning and cognitive abilities were almost equal. The second year, EG1 were taught with the subject content course Experimental Design the English original material as the course material in English teaching in the regular classroom, EG2 were taught with the subject content course Experimental Design the English original material as the course material in English teaching in the Internet-Based Language Laboratory. CG were continued to learn conventional English course material College English, which focused on learning the form of the language and on teachers' teaching the knowledge of the language in the text. The survey found that before the experiment, EG and CG showed no significant difference in learning motivation level $(\mathrm{t}=.137, p=.435)$ 
(Table 1$)$ and $(\mathrm{t}=.134, p=.431)$ (Table 2). Meanwhile, three groups of students in English language ability were not significantly different $(\mathrm{t}=.161, p=.946)$ (Table 3$)$. Therefore, we can say that EG and CG were homogeneous before the experiment.

Table 1. Test of English learning motivation between CG and EG1.

\begin{tabular}{|c|c|c|c|c|c|c|c|}
\hline & & \multicolumn{2}{|c|}{$\mathrm{CG}(\mathrm{N}=30)$} & \multicolumn{2}{|c|}{ EG1 $(\mathrm{N}=30)$} & \multirow[b]{2}{*}{$\mathrm{t}$} & \multirow[b]{2}{*}{$p$} \\
\hline & & M & $\mathrm{S}$ & M & $\mathrm{S}$ & & \\
\hline \multirow{3}{*}{ Pretest } & MS & 2.12 & .41 & 2.16 & .42 & .354 & .172 \\
\hline & DL & 2.14 & .41 & 2.23 & .44 & -.215 & .264 \\
\hline & Total & 4.26 & .80 & 4.39 & .85 & .137 & .435 \\
\hline \multirow{3}{*}{$\begin{array}{l}\text { After } \\
\text { the experiment }\end{array}$} & MS & 2.16 & .42 & 2.27 & .47 & -1.52 & .055 \\
\hline & DL & 2.27 & .44 & 2.37 & .47 & -1.07 & $.021^{*}$ \\
\hline & Total & 4.43 & .85 & 4.64 & .90 & -2.49 & $.023^{*}$ \\
\hline
\end{tabular}

"means $p \leq .05$, C.G. for Control Group; E.G. for Experimental Group; MS for Motivation Strength; DL for Desire of Learning.

Table 2. Test of English learning motivation between CG and EG2.

\begin{tabular}{|c|c|c|c|c|c|c|c|}
\hline & & \multicolumn{2}{|c|}{ CG $(\mathrm{N}=30)$} & \multicolumn{2}{|c|}{ EG2(N = 30) } & \multirow[b]{2}{*}{$\mathrm{t}$} & \multirow[b]{2}{*}{$p$} \\
\hline & & M & S & M & S & & \\
\hline \multirow{3}{*}{ Pretest } & MS & 2.12 & .41 & 2.15 & .41 & .354 & .172 \\
\hline & DL & 2.14 & .41 & 2.21 & .42 & -.215 & .264 \\
\hline & Total & 4.26 & .80 & 4.36 & .82 & .134 & .431 \\
\hline \multirow{3}{*}{$\begin{array}{c}\text { After } \\
\text { the experiment }\end{array}$} & MS & 2.16 & .42 & 2.31 & .44 & -1.42 & $.045^{*}$ \\
\hline & DL & 2.27 & .44 & 2.39 & .45 & -1.03 & $.020^{*}$ \\
\hline & Total & 4.43 & .85 & 4.70 & .86 & -2.41 & $.013^{*}$ \\
\hline
\end{tabular}

${ }^{*}$ means $p \leq .05$, C.G. for Control Group; E.G. for Experimental Group; MS for Motivation Strength; DL for Desire of Learning.

Table 3. Test of English applied ability between CG and EG1.

\begin{tabular}{|c|c|c|c|c|c|c|c|}
\hline & & \multicolumn{2}{|c|}{ CG $(\mathrm{N}=30)$} & \multicolumn{2}{|c|}{ EG1 $(\mathrm{N}=30)$} & \multirow[b]{2}{*}{$\mathrm{t}$} & \multirow[b]{2}{*}{$p$} \\
\hline & & M & S & M & S & & \\
\hline \multirow{4}{*}{ Pretest } & Writing & 135.93 & 18.18 & 135.23 & 18.10 & .38 & .71 \\
\hline & Listening & 139.67 & 21.11 & 138.40 & 20.45 & 1.42 & .17 \\
\hline & Reading & 138.80 & 23.09 & 139.23 & 22.83 & -.70 & .49 \\
\hline & Oral English & 8.97 & 1.56 & 8.87 & 1.47 & 1.00 & .33 \\
\hline \multirow{4}{*}{$\begin{array}{l}\text { After the } \\
\text { experiment }\end{array}$} & Writing & 136.23 & 16.83 & 137.03 & 16.86 & -.41 & .69 \\
\hline & Listening & 140.73 & 20.00 & 141.00 & 17.90 & -.21 & .84 \\
\hline & Reading & 140.17 & 22.24 & 140.07 & 21.73 & .09 & .93 \\
\hline & Oral English & 9.07 & 1.51 & 9.00 & 1.36 & .44 & .66 \\
\hline
\end{tabular}

${ }^{*}$ means $p \leq .05$, C.G. stands for Control Group; E.G. stands for Experimental Group. 


\subsection{Research Design}

The study was to investigate that 1) Compared with CG, did content-based instruction (CBI) and content-based instruction (CBI) with IBLL support both help non-English-majored undergraduate students improve their motivation to learn English? If the answer was yes, which method would be better (CBI or CBI with IBLL support)? 2) Compared with CG, did content-based instruction (CBI) and content-based instruction (CBI) with IBLL support both help non-English-majored undergraduate students improve their English language proficiency? If the answer was yes, which method would be better (CBI or CBI with IBLL support)? 3) Were both CBI and CBI with IBLL support beneficial to all undergraduate students of EG1 and EG2 in the study in English learning? A comparative research method was used in this study.

\subsection{Instruments}

The instruments used in this study were the English Learning Motivation Questionnaire, tests of English Language Applied Ability and interviews

English Learning Motivation. Gardner \& Lamber's language learning motivation, attitude/motivation test Scale AMTB (Attitude/Motivation Test Battery), as the survey tool in this study was used to measure non-English-majored undergraduate students' English language learning motivation, and desire that the three-point Likert scale for scale, a total of 20 questions, which related to the motivation and desire 10 questions respectively. Prediction of internal reliability was .90, meaning that the scale display was reliable.

English Language Applied Ability. The National College English Test band 4 (2013 New Style) (full score of 710) and the National CET Oral Test (full score of 15) as the English language tools were used in this study to test the ability of non-English-majored undergraduate students to use English. Content of CET 4 were showed in Table 2.

Interviews. There were interviews with all 60 students in EG1 and EG2 about the course experimental design and the harvest of learning English through the subject content by CBI or CBI with IBLL support. The teacher wrote down all interviews with all 60 students in EG about the course experimental design and the harvest of learning English through the subject content by CBI or CBI with IBLL support.

\subsection{Data Collection and Analyses}

Before the research experiment (September 2014) and after the experiment (June 2015) three surveys on English learning motivation and three tests on English language applied ability were conducted to compare changes between the three groups of students in English learning motivation and the ability to use English. In this study, social scientific software SPSS 15.0 was used for statistical analysis to the collected data, the results showed that, the internal consistency reliability of the use of questionnaires and survey papers reached more than .78, indicating that the test results were reliable. In order to find out CBI and CBI with IBLL support proved superior to the conventional teaching (such as grammar-translation) method, comparison of Means was adopted to compare three groups of non-English-majored undergraduate students' average scores of their pretest and after the experiment on the basis of samples. And the independent sample T-test was adopted to exanimate if there were significances between CG and EG before the experiment and after the experiment.

\section{Course Content and Teaching Organization Process}

This experiment was carried out one year, the implementation details were shown in Table 4. English classroom teaching time for CG and EG was, respectively, 4 hours per week, reading, and writing listening and speaking lessons taught by the same English teacher. EG1 were taught with teaching mode CBI in the regular classroom same as CG, Experimental Design used as subject material, and the experimental accuracy, the experiment results of statistical analysis, random design, and factor experiment design involved as the subject content. Students in EG1 read the content of the relevant chapters before class, teaching activities for EG1 in class were teachers answering questions from students or solving problems from students who did not understand the subject content they read, a topic presentation made by students from EG1, group discussion and question answering between students in EG1 and so on. EG2 were taught with teaching mode CBI in the Internet-Based Language Laboratory, Experimental Design used as subject material, and the experimental accuracy, the experiment results of statistical analysis, random design, and factor experiment design involved as the subject content. Stu- 
Table 4. Comparison of teaching content and teaching process between CG and EG.

\begin{tabular}{|c|c|c|}
\hline Groups Items & CG & EG \\
\hline $\begin{array}{c}\text { Teaching } \\
\text { content }\end{array}$ & $\begin{array}{l}\text { Priority to English language knowledge, } \\
\text { interpretation of the text content for students } \\
\text { acquiring language knowledge }\end{array}$ & $\begin{array}{c}\text { Priority to experimental design knowledge and } \\
\text { linguistic knowledge as } \\
\text { complementary (for EG1 and EG2) }\end{array}$ \\
\hline Schedules & $\begin{array}{l}2 \text { hours for the teacher's teaching reading and writing } \\
\text { (the teacher explaining language points, students answering } \\
\text { a few questions); } 2 \text { hours for non-English-majored } \\
\text { graduate students listening to listening material from } \\
\text { textbooks and College English Test (CET) Level } 6\end{array}$ & $\begin{array}{l}2 \text { hours for the teacher's teaching reading and writing } \\
\text { (the teacher explaining related chapters, at the same } \\
\text { time, students exploring chapters content and design } \\
\text { of experiment in English) (for EG1 and EG2); } 2 \text { hours } \\
\text { for listening (via Internet to download audio and } \\
\text { video data to discuss design of experiment) (for EG2) }\end{array}$ \\
\hline $\begin{array}{l}\text { Language } \\
\text { material }\end{array}$ & $\begin{array}{l}\text { Domestic non-English-majored graduate } \\
\text { students textbooks } \\
\text { and College English Test(CET) Level } 6 \text { papers }\end{array}$ & $\begin{array}{l}\text { Original English textbooks (for EG1 and EG2), } \\
\text { English audio and video materials, and English } \\
\text { programs on the network (for EG2) }\end{array}$ \\
\hline $\begin{array}{l}\text { Teaching } \\
\text { language }\end{array}$ & Combination of Chinese and English & English ((for EG1 and EG2)) \\
\hline $\begin{array}{l}\text { Teaching } \\
\text { activities }\end{array}$ & $\begin{array}{l}\text { Priority to the } \\
\text { explanation, and little interaction } \\
\text { between teachers and students }\end{array}$ & $\begin{array}{l}\text { Teacher's explanation as complementary; } \\
\text { more presentations and discussions between } \\
\text { students; Interaction between teachers and students; } \\
\text { Communication between students (for EG1 and EG2) }\end{array}$ \\
\hline $\begin{array}{l}\text { Teaching } \\
\text { means }\end{array}$ & $\begin{array}{l}\text { Reading and writing lessons in regular classrooms; } \\
\text { listening lessons in language-learning lab }\end{array}$ & $\begin{array}{l}\text { Reading and writing lessons in regular classrooms; } \\
\text { listening lessons in language-learning lab (for EG1) } \\
\text { All the lessons in classrooms with network } \\
\text { and multimedia equipment (for EG2) }\end{array}$ \\
\hline
\end{tabular}

dents in EG2 read the content of the relevant chapters before class, teaching activities for EG2in class were teachers answering questions from students or solving problems from students who did not understand the subject content they read, a topic presentation made by students from EG2, group discussion and question answering between students in EG2. Students in EG2 could ask for or communicate with more persons about the subject content through the internet and so on.

In class, for EG1, the teacher's explanation for subject content were conducted by power point (PPT). For EG2, in class, the teacher's explanation for subject content and student's statements for subject content were conducted in Internet-Based Language Laboratory, with broadcast audio and video materials to help students understand the course content knowledge. For EG1 and EG2, English used as the teaching language in teaching activities, students in EG were encouraged by the teacher to communicate freely about the subject content in English, and to interpreter, induce and analyze the facts and opinions in the subject content. New Horizon College English (intensive reading) used as the teaching material for CG, teachers mainly adopted the combination of teaching methods for CG: grammar-translation and listening, and explained language knowledge and the text content, students answered the questions from the teacher on the text.

\section{Results}

In this study, social sciences software (SPSS17.0) was used for statistical analysis to the collected data to obtain relevant results, and the results were analyzed.

\subsection{English Learning Motivation}

After the one-year experiment, non-English-majored undergraduate students' English learning motivation were improved between CG and EG. At the end of the experiment, CG was lower than EG1 in the overall level of learning motivation $(\mathrm{t}=-1.52, p=.055)$, while CG was less strong desire than EG1 to learn English $(\mathrm{t}=-1.07$, $p=.021$ ) (Table 1). And, at the end of the experiment, CG was lower than EG2 in the overall level of learning motivation ( $\mathrm{t}=-1.42, p=.045)$, while CG was less strong desire than EG2 to learn English $(\mathrm{t}=-1.03, p=.020)$ (Table 2). After the one-year experiment , from Table 1 and Table 2, compared with CG, the method of combining CBI with IBLL support were better than the method of only CBI in developing non-English-majored undergraduate students’ English learning motivation. 


\subsection{English Applied Ability}

As showed in Table 3, after one-year experiments, the ability to use the English language in CG and EG1 were improved, but the ability of the non-English-majored undergraduate students in CG to use English was, in general, lower than that of EG1. CG was inferior to EG1, compared to the increase in the output of the skills, such as writing $(\mathrm{t}=-.41, p=.69)$ and oral English $(\mathrm{t}=-.44, p=.66)$, indicating that English writing skills and spoken English skills of the non-English-majored undergraduate students in EG1 had been significantly improved. CG was significantly inferior to EG1 on the skills of reception, such as listening $(\mathrm{t}=-.21, p=.84)$ and reading $(\mathrm{t}=.09, p=.93)$, which showed that EG1 in English Listening comprehension and reading comprehension had improved significantly.

As showed in Table 5, after one-year experiments, the ability to use the English language in CG and EG2 were improved, but the ability of the non-English-majored undergraduate students in CG to use English was, in general, lower than that of EG2. And there were significant differences between CG and EG2 from Writing ability to Oral English Specifically, CG was significantly inferior to EG2, compared to the increase in the output of the skills, such as writing $(\mathrm{t}=-2.13, p=.04)$ and oral $(\mathrm{t}=-2.31, p=.03)$, indicating that English writing skills and spoken English skills of the non-English-majored undergraduate students in EG2 had been significantly improved. CG was significantly inferior to EG2 on the skills of reception, such as listening $(\mathrm{t}=-2.25, p=.03)$, and reading $(\mathrm{t}=-2.05, p=.05)$, which showed that EG1 in English Listening comprehension and reading comprehension had improved significantly. After the one-year experiment, from Table 3 and Table 5, compared with CG, the method of combining CBI with IBLL support were better than the method of only CBI in developing non-English-majored undergraduate students’ English applied ability..

\subsection{Interview}

After the experiment, the teacher had interviews with 30 students in EG1 about the course experimental design and the harvest of learning English through the subject content, and 30 students in EG2 about the course experimental design taught in IBLL and the harvest of learning English through the subject content in IBLL. 22 students from EG1 said that their English ability (writing, listening, reading and oral English) was improved a lot. 8 students from EG1 said that their English ability (writing, listening, reading and oral English) was improved a little. 25students from EG2 said that their English ability (writing, listening, reading and oral English) was improved a lot. 5 students from EG2 said that their English ability (writing, listening, reading and oral English) was improved a little.

\section{Discussion}

The non-English-majored undergraduate students' development of learning motivation and learning motivation was an important factor in the development of English language learning to achieve their English language

Table 5. Test of English applied ability between CG and EG2.

\begin{tabular}{|c|c|c|c|c|c|c|c|}
\hline & & \multicolumn{2}{|c|}{ CG $(\mathrm{N}=30)$} & \multicolumn{2}{|c|}{ EG2 $(\mathrm{N}=30)$} & \multirow[b]{2}{*}{$\mathrm{t}$} & \multirow[b]{2}{*}{$\mathrm{p}$} \\
\hline & & M & S & M & S & & \\
\hline \multirow{4}{*}{ Pretest } & Writing & 135.93 & 18.18 & 136.20 & 18.96 & -.21 & .83 \\
\hline & Listening & 139.67 & 21.11 & 140.73 & 21.07 & -.93 & .36 \\
\hline & Reading & 138.80 & 23.09 & 137.53 & 32.75 & .28 & .78 \\
\hline & Oral English & 8.97 & 1.56 & 8.93 & 1.55 & .44 & .66 \\
\hline \multirow{4}{*}{$\begin{array}{l}\text { After the } \\
\text { experiment }\end{array}$} & Writing & 136.23 & 16.83 & 138.00 & 18.60 & -2.13 & $.04^{*}$ \\
\hline & Listening & 140.73 & 20.00 & 143.57 & 18.63 & -2.25 & $.03^{*}$ \\
\hline & Reading & 140.17 & 22.24 & 141.97 & 4.07 & -2.05 & $.05^{*}$ \\
\hline & Oral English & 9.07 & 1.51 & 9.13 & .27 & -2.31 & $.03^{*}$ \\
\hline
\end{tabular}

"means $p \leq .05$, C.G. stands for Control Group; E.G. stands for Experimental Group. 
learning goals. Seen in Tables 1-3 and Table 5, we know that, after the one-year experiment CG was lower than EG in the overall level of learning motivation, especially the desire to learn English, and English applied ability.

The main reasons are:

First, English courses were required by non-English-majored undergraduate students. When teaching the content of English course was related to the interest of learners, non-English-majored undergraduate students would have a strong desire to learn subject content related to or being useful for their majors, this correlation was a prerequisite for maintaining long-term motivation to learn. Some of students in EG already had a strong interest in learning English, the teachers chose English language as a medium to teach curriculum content and design of experiments to help students learn needed academic subject knowledge. After the experiment, interviewed with the students in EG, we knew that they thought that English as a medium to learn to gain academic subject knowledge promoted the development of their English learning motivation. Especially, non-English-majored undergraduate students in EG2 thought that English as a medium to learn to gain academic subject knowledge in the Inter-Based Language Laboratory was not only to promote the development of their English learning motivation and desire, but also to provide them to communicate with other persons interested in the subject content and gain more ideas to solve the problems about the subject content through the help of Internet.

Second, the content of course was combined the real experimental content with real language content for non-English-majored undergraduate students in EG1 and EG2 to learn English and the subject content. In this study, original content-based English teaching materials was used for English teaching and learning textbooks, which was helpful for students to develop their own experimental design. Students' learning motivation changed gradually from the instrumental motivation to integrative motivation. Especially, non-English-majored undergraduate students in EG2 not only learned the subject content Experimental Design from the textbook, but also learned the subject content Experimental Design from multiple aspects such as watching Video, newspapers and discussion via the inter.

Therefore, the combined effects of differences on overall academic achievement among the three groups of students were contributed to the internal and external factors from three groups of non-English-majored undergraduate English language learners in the experiment. Students in the experimental groups listened to teachers explain the subject content knowledge in English, and EG2 listened to and watched English information related to the subject through IBLL. After class, both EG1 and EG2, they listened to and watched English programs related to the course, so that they had a lot of time in English listening environment to improve their listening ability and oral English ability of a great help.

After the interviews with non-English-majored undergraduate students in EG, the researcher in this study knew that some non-English-majored undergraduate students in EG1 with poor basic English foundation in this study said that they felt English learning pressure increased a lot and their ability to use the English language to be improved was not obvious in CBI because both the teacher explained the subject content with English and discussion related to the subject was done between non-English-majored undergraduate students also with English, which caused some students with poor basic English foundation more pressure in listening and expressing through English. Other non-English-majored undergraduate students in EG2 with poor basic English foundation in this study said that they felt English learning pressure increased and their ability to use the English language to be improved was not obvious in combining CBI with IBLL support because the teacher explained the subject content with English , discussion related to the subject done between non-English-majored undergraduate students with English and videos related to the subject content displayed in English in IBLL, which caused some students with poor basic English foundation a lot of pressure in listening and expressing through English. This indicated that the method of CBI or the method of combining CBI with IBLL support was limited to help non-English-majored undergraduate students with poor English basis.

\section{Limitations and Suggestions for Further Research}

Though the present study has provided a comparatively detailed description of CBI with IBLL support applied among some second-year non-English-majored undergraduate students, there are still some limitations of the study. Having the limitations in mind, suggestions for further research, therefore, can be put forward at the same time in order to achieve a lot thorough understanding of CBI with IBLL support.

Firstly, being time limitation (only one year) and other practical restrictions such as the subjects in the study consisted of only 90 non-English-majored undergraduate students in one university need to be broadened in further research. 
Secondly, the instruments used to investigate non-English-majored undergraduate English teaching with CBI with IBLL support involve structured questionnaire, tests and interviews. The study would be much better, if it were combined with other instruments such as observation, verbal report. More instruments should be used in investigation in further research.

Finally, CBI with IBLL support applied in non-English-majored undergraduate English teaching can improve non-English-majored undergraduate students' English learning and their course learning, but CBI with IBLL support also works for other subjects such as senior school students, we need further research.

Despite of the restraints of the study, it is hoped that it can offer some guidelines for further research on CBI with IBLL support applied in English teaching.

\section{Conclusion}

College English is a required course for every student in colleges or universities in mainland China. The purpose of College English teaching in mainland China is to develop students' English language proficiency, especially in listening and speaking skills, so that they can use English to communicate effectively in the future study, work and social interactions, while enhancing their self-learning ability and cultural awareness to adapt to the development of our society and to meet the need for international exchanges. 90 non-English-majored undergraduate students in Yangtze University participated in this study for one-year experiment to investigate effects of CBI English teaching with IBLL support. Results in this study showed that 1) compared with the control group (CG), both CBI English teaching and CBI English teaching with IBLL support could improve the level of English learning motivation of non-English-majored undergraduate students in their English learning, and CBI English teaching with IBLL support is better in enhancing the level of English learning motivation; 2) compared with the control group (CG), both CBI English teaching and CBI English teaching with IBLL support could improve the level of English language applied ability of non-English-majored undergraduate students in their English learning, and CBI English teaching with IBLL support is better in enhancing the level of English language applied ability; 3) both CBI English teaching and CBI English teaching with IBLL support are limited for some non-English-majored undergraduate students with poor foreign language (English) basis.

\section{References}

Benesch, S. (1988). Linking Content and Language Teachers: Collaboration across the Curriculum. In S. Benesch (Ed.), Ending Remediation: Linking ESL and Content in Higher Education. Washington DC: Teachers of English to Speakers of Other Languages.

Brinton, D. M., Snow, M. A., \& Wesche, M. B. (1989). Content-Based Second Language Instruction. New York: Harper \& Row.

Chumpavan, S. A (2001). Comparative Study of Two English as a Foreign Language (EFL) Programs: Non-Content-Based and Content-Based at the University Level in Thailand. Ph.D. Dissertation, Normal: Illinois State University.

Crandall, J. (1999). Content-Based Instruction (CBI). Concise Encyclopedia of Educational Linguistics (pp. 208-604). Oxford, UK: Cambridge University Press.

Kasper, L. F. (1994). Improved Reading Performance for ESL Students through Academic Course Pairing. Journal of Reading, 5, 376-384.

Kasper, L. F. (1997). The Impact of Content-Based Instructional Programs on the Academic Progress of ESL Students. English f or Specific Purposes, 4, 309-320. http://dx.doi.org/10.1016/S0889-4906(97)00035-5

Li, L. S. (2002). Sustained-Content Language Teaching Mode and Its Enlightenment to College English Teaching Reform in China. Foreign Language World, 4, 36-40.

Lv, L. H. (2001). The Integration of Language and Content-Trend of Foreign Language Teaching Reform. Global Education, 8, 52-56.

Mohan, B. A. (1986). Language and Content. Reading, MA: Addison-Wesley.

Richards, J., \& Rodgers, T. (2001). Approaches and Methods in Language Teaching (p. 204). New York: Cambridge University Press. http://dx.doi.org/10.1017/CBO9780511667305

Valeo, A. (2013). The Integration of Language and Content: Form-Focused Instruction in a Content-Based Language Program. Canadian Journal of Applied Linguistics, 16, 25-50.

Yu, L. M., \& Han, J. X. (2003). Based on Course Teaching in Ottawa and Its Enlightenment. Foreign Language Teaching and Research, 3, 465-468. 